\title{
Effect of thermo-tolerant yeast on intake and nutrient digestibility's in Murrah buffalo steers (Bubalus bubalis) fed straw based complete diet
}

\author{
B. Bhima ${ }^{1}$, Y. Ramana Reddy ${ }^{2}$, M. Sudhakara Reddy ${ }^{1}$, M. Pawani ${ }^{2}$ and L. Venkateswar Rao ${ }^{1}$
}

1. Department of Microbiology, University College of Science, Osmania University, Hyderabad - 500 007, Andhra Pradesh, India; 2. Department of Animal Nutrition, College of Veterinary Science, Sri Venkateshwara Veterinary University, Rajendranagar, Hyderabad - 500 030, Andhra Pradesh, India.

Corresponding author: B. Bhima, email: bhima.ou@gmail.com, Tel: +91-9494441624

YRR: ramanayr19@yahoo.co.in, MSR: sudhabios@gmail.com, MP: pawani_mitta@yahoo.com: LVR: vrlinga@gmail.com Received: 27-04-2014, Revised: 10-06-2014, Accepted: 13-06-2014, Published online: 19-07-2014

doi: 10.14202/vetworld.2014.501-504 How to cite this article: Bhima B, Ramana Reddy Y, Sudhakara Reddy M, Pawani M and Venkateswar Rao L (2014) Effect of thermo-tolerant yeast on intake and nutrient digestibility's in Murrah buffalo steers (Bubalus bubalis) fed straw based complete diet, Veterinary World 7(7): 501-504.

\begin{abstract}
Aim: In the present study, we determined the effect and optimum level of inclusion of a thermo-tolerant probiotic Saccharomyces cerevisiae OBV9 on nutrient intake and digestibilities in Murrah buffaloes (Bubalus bubalis).

Materials and Methods: A straw based complete diet (crude protein (CP) 12\%) with $0.1,0.2$ and $0.3 \%$ of lyophilized yeast was evaluated in a 4 X4 Latin Square metabolism trial in fistulated Murrah buffalo steers (223.81 kg \pm 2.91$)$. Diet with no yeast was taken as control.

Results: Dry matter intake (DMI) was not significantly $(\mathrm{P}>0.05)$ influenced by any level $(\%)$ of yeast in complete diet. The digestibility's $(\%)$ of dry matter $(\mathrm{DM})$ and crude fibre $(\mathrm{CF})$ were significantly $(\mathrm{P}<0.05)$ higher in $0.1 \%$ yeast supplemented diet compared to control, whereas organic matter, $\mathrm{CP}$, ether extract and nitrogen free extract were not influenced by yeast treatments. The digestibility's of neutral detergent fibre (NDF), acid detergent fibre (ADF), hemicellulose, cellulose, total digestible nutrients $(\mathrm{TDN} \%)$ and metabolizable energy $(\mathrm{ME}$ as $\mathrm{MJ} / \mathrm{kg} \mathrm{DM})$ were significantly $(\mathrm{P}<0.05)$ higher in yeast supplemented diets compared to control. However, among the yeast supplemented diets the values were not $(\mathrm{P}>0.05)$ different

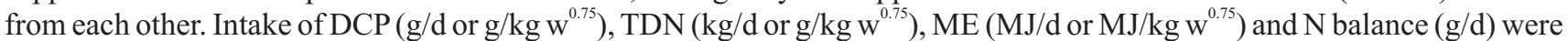
$\operatorname{not}(\mathrm{P}>0.05)$ affected by the level of yeast in the diet.

Conclusion: It can be concluded that, $0.1 \%$ thermo-tolerant yeast had greater influence on majority of the nutrients in the straw based complete diets of Murrah buffaloes.
\end{abstract}

Keywords: buffalo steers, complete diet, nitrogen balance, nutrient digestibility, thermo-tolerant yeast.

\section{Introduction}

Dietary supplementation of probiotic yeast (Saccharomyces cerevisiae) was noted to improve the animal performance by improving the digestibility of nutrients and rumen bacterial number [1]. Addition of yeast culture, as a probiotic, in animal feeds improves fibre digestion [2], the cellulolytic activity of rumen microbes [3], and reduces the lactate accumulation and oxygen concentration in rumen fluid. Many studies did not find any difference in dry matter intake and nutrient digestibility's by supplementing yeast to buffaloes [4, 5]. Ineffectiveness of yeast culture supplementation on productive performance of cattle is attributed to its instability at $39^{\circ} \mathrm{C}[6]$, pressure and volatile fatty acid concentrations [7] in the rumen.

Normally yeast $S$. cerevisiae grows at mesophilic temperature $\left(30^{\circ} \mathrm{C}\right)$ and $\mathrm{pH}$ range of 4.5 - 5.5 [8]. Since the rumen environment is so diversified, some strains of yeast may not be resistant to the rumen environment before they become effective. Considering the inconsistencies observed on growth and nutrient digestibilities with yeast supplementation, we have selected a thermo-

Copyright: The authors. This article is an open access article licensed under the terms of the Creative Commons Attribution License (http://creativecommons.org/licenses/by/2.0) which permits unrestricted use, distribution and reproduction in any medium, provided the work is properly cited. tolerant $S$. cerevisiae OBV9 which is stress resistant and be able to grow at temperatures above $39{ }^{\circ} \mathrm{C}$, as in the rumen [9].

The purpose of the present study was to evaluate the effect of yeast strain OBV9 on intake and nutrient digestibility's in Murrah buffalo steers.

\section{Materials and Methods}

Ethical approval: Animal experiment was conducted at the Livestock Experimental Station, Livestock Research Institute, College of Veterinary Science, Sri Venkateshwara Veterinary University, Rajendranagar, Hyderabad. The experimental design and plan of the study was approved by the Institutional Animal Ethics Committee.

Selection of thermo-tolerant yeast (S. cerevisiae) strain: The yeast strain OBV9 used in the present study was isolated by our group from brewery effluents and screened for its growth under different stress conditions such as temperature, $\mathrm{pH}$, bile concentration and osmotic pressure which mimics the rumen condition [9].

Experimental animals: Four fistulated Murrah buffalo steers of uniform body weight $(223.81 \mathrm{~kg} \pm 2.91)$ were used in a $4 \times 4$ Latin square design (LSD) to find out the effective level of inclusion of $S$. cerevisiae OBV9 in the 
Table-1: Ingredient and chemical composition (\%) of the experimental complete ration.

\begin{tabular}{|c|c|}
\hline Ingredient & Composition (\%) \\
\hline Sorghum straw & 40.0 \\
\hline Maize & 14.0 \\
\hline Groundnut cake & 12.5 \\
\hline Sunflower cake & 15.0 \\
\hline Deoiled rice bran & 10.0 \\
\hline Molasses & 7.0 \\
\hline Mineral mixture & 1.0 \\
\hline Salt & 0.5 \\
\hline Total $^{*}$ & 100 \\
\hline \multicolumn{2}{|c|}{ Nutrient proximate principle $^{\dagger}$} \\
\hline Dry matter & 88.65 \\
\hline Organic matter & 88.98 \\
\hline Crude protein & 11.88 \\
\hline Ether extract & 1.90 \\
\hline Crude fiber & 24.27 \\
\hline Nitrogen free extract & 48.94 \\
\hline Total ash & 11.02 \\
\hline \multicolumn{2}{|l|}{ Cell wall constituents ${ }^{\dagger}$} \\
\hline Neutral detergent fibre & 51.82 \\
\hline Acid detergent fibre & 33.13 \\
\hline Hemicellulose & 18.69 \\
\hline Cellulose & 24.70 \\
\hline Lignin & 4.75 \\
\hline
\end{tabular}

* Vitamin $\mathrm{AD}_{3}$ is added @ $10 \mathrm{~g} / 100 \mathrm{~kg}$; † Each value is an average of triplicate analysis on DM basis except for DM
Table-2: Effect of different levels of thermo tolerant yeast in complete ration on dry matter intake (DMI) and nutrient digestibility in Murrah buffalo steers.

\begin{tabular}{lccccc}
\hline Parameter $^{\dagger}$ & \multicolumn{4}{c}{ Level of yeast (\%) } & SEM \\
\cline { 2 - 5 } & $\mathbf{0 . 0}$ & $\mathbf{0 . 1}$ & $\mathbf{0 . 2}$ & $\mathbf{0 . 3}$ & \\
\hline Body weight (kg) & 224.3 & 221.1 & 222.3 & 227.6 & 2.91 \\
Metabolic body weight (kg) & 57.86 & 57.30 & 57.53 & 58.55 & 0.58 \\
DMl (kg/d) & 7.39 & 7.31 & 7.44 & 7.31 & 0.30 \\
DMl (g/kgw .75 $^{\dagger}$ ) & 129.0 & 128.1 & 129.9 & 125.6 & 1.31 \\
Nutrient digestibility (\%) & & & & & \\
Dry matter & $53.94^{\mathrm{a}}$ & $57.14^{\mathrm{b}}$ & $57.02^{\mathrm{b}}$ & $56.68^{\mathrm{b}}$ & 0.52 \\
Organic matter & 60.19 & 62.67 & 62.55 & 61.96 & 0.56 \\
Crude protein & 67.19 & 71.47 & 70.77 & 70.95 & 1.40 \\
Ether extract & 71.99 & 73.47 & 74.53 & 73.33 & 1.57 \\
Crude fibre & $50.39^{\mathrm{a}}$ & $53.55^{\mathrm{b}}$ & $54.08^{\mathrm{b}}$ & $53.67^{\mathrm{b}}$ & 0.81 \\
Nitrogen free extract & 64.85 & 66.66 & 66.59 & 65.90 & 0.53 \\
Cell wall constituents (\%) & & & & & \\
Neutral detergent fibre & $52.03^{\mathrm{a}}$ & $56.54^{\mathrm{b}}$ & $55.72^{\mathrm{b}}$ & $56.53^{\mathrm{b}}$ & 1.83 \\
Acid detergent fibre & $46.94^{\mathrm{a}}$ & $50.87^{\mathrm{b}}$ & $50.73^{\mathrm{b}}$ & $49.99^{\mathrm{b}}$ & 0.67 \\
Hemicellulose & $64.28^{\mathrm{a}}$ & $67.66^{\mathrm{b}}$ & $67.69^{\mathrm{b}}$ & $67.52^{\mathrm{b}}$ & 0.45 \\
Cellulose & $59.75^{\mathrm{a}}$ & $63.34^{\mathrm{b}}$ & $62.75^{\mathrm{b}}$ & $63.20^{\mathrm{b}}$ & 0.62 \\
\hline
\end{tabular}

†Each value is an average of four observations; ab - values bearing different superscripts in a row differ significantly $(P<0.05)$ straw based diet in comparison to control diet (without yeast supplementation). All the buffalo steers were dewormed before inducting into the experiment and vaccinated against FMD.

Experimental diets and feeding: A complete ration (CP $12 \%$ ) was formulated using locally available feedstuffs such as sorghum straw (roughage base), maize, groundnut cake, sunflower cake, de-oiled rice bran and molasses (concentrate base) and supplemented with $0.1,0.2$ and $0.3 \%$ level of lyophilized $\left(1.8 \times 10^{9} \mathrm{cfu} / \mathrm{g}\right)$ thermo-tolerant yeast, Saccharomyces cerevisiae OBV-9. During the metabolism trial buffalo steers were fed twice a day i.e. at $9 \mathrm{AM}$ and $3 \mathrm{PM}$. Potable drinking water was offered ad libitum throughout the experiment. The ingredients and chemical composition of experimental straw based diet is given in Table-1.

Metabolism trial: A 15-day preliminary period and a 7day collection period were followed during the metabolism trial. During the collection period, feed intake of individual animal was quantified based on feed refusal of each day. For chemical analysis, samples of feed offered and residues leftover were collected in separate polythene bags for each animal daily [10]. Faeces and urine collected after $24 \mathrm{~h}$ were recorded at $08.00 \mathrm{~h}$. Aliquots of faeces $(0.10 \mathrm{w} / \mathrm{w})$ and urine $(0.05$ $\mathrm{v} / \mathrm{v}$; with few drops of conc. $\mathrm{HCl}$ ) were taken and stored at $-20^{\circ} \mathrm{C}$ and $4{ }^{\circ} \mathrm{C}$, respectively till further processing. After completion of each collection period, frozen faecal samples were thawed, homogenized and subsampled for Nitrogen (N) and dry matter (DM) determination. For further chemical analysis, faecal material was dried, ground through a $1 \mathrm{~mm}$ screen in a Wiley mill and stored in air tight bottles. Feed samples were also prepared similarly for analysis [11].

Chemical analysis: Samples of experimental feed, leftover residues, feces and urine were collected and analyzed for $\mathrm{N}$ using 'Turbotherm' and 'Vapodest' (Gerhard, Germany) analyzer based on the principle of Micro-Kjeldahl method [12]. The DM, total ash, ether extract and crude fibre were determined according to the procedures described by AOAC (1997) [12]. NDF and ADF of feeds and faeces were analyzed as described by Van Soest et al. [13]. Hemicellulose was calculated as NDF-ADF. ME values were calculated based on NRC (1978) [14] formulae (1 kg TDN = 17.45 MJ DE; $\mathrm{ME}=\mathrm{DE} \times 0.82)$.

Statistical analysis: The data obtained through in vivo studies were analyzed statistically [15] and tested for significance by Duncan's multiple range test [16].

\section{Results}

Effect on intake and nutrient digestibility: As evident from Table-2, DMI ( $\mathrm{kg} / \mathrm{d}$ or g/ $\left.\mathrm{kg} \mathrm{w}^{0.75}\right)$ of straw based complete diet was not affected $(\mathrm{P}>0.05)$ by the levels of OBV9 fed to Murrah buffalo steers. The digestibility's (\%) of DM and CF were significantly $(\mathrm{P}<0.05)$ higher in yeast-supplemented diet compared to control. Similarly, the digestibility's of NDF, ADF, hemicellulose and cellulose were $(\mathrm{P}<0.05)$ higher in diets-supplemented with yeast compared to control (Table-2). However, increased levels of yeast from $0.1 \%$ to $0.3 \%$ had no effect $(\mathrm{P}>0.05)$ on the digestibility's of OM, CP, EE, NFE and cell wall constituents (Table-2).

Nutritive value and nutrient intake: The TDN (\%) and metabolizable energy ( $\mathrm{ME}$ as $\mathrm{MJ} / \mathrm{kg} \mathrm{DM}$ ) were significantly $(\mathrm{P}<0.05)$ higher in yeast-supplemented 
Table-3: Effect of different levels of thermo-tolerant yeast in complete ration on nutritive value, plane of nutrition and nitrogen $(\mathrm{N})$ balance in Murrah buffalo steers

\begin{tabular}{|c|c|c|c|c|c|}
\hline \multirow[t]{2}{*}{ Parameter $^{\dagger}$} & \multicolumn{4}{|c|}{ Level of yeast (\%) } & \multirow[t]{2}{*}{ SEM } \\
\hline & 0.0 & 0.1 & 0.2 & 0.3 & \\
\hline DCP (\%) & 8.02 & 8.53 & 8.45 & 8.47 & 0.17 \\
\hline TDN (\%) & $55.05^{\mathrm{a}}$ & $57.28^{\mathrm{b}}$ & $57.34^{b}$ & $56.87^{\mathrm{b}}$ & 0.68 \\
\hline $\begin{array}{l}\text { ME (MJ/kgDM ) } \\
\text { Intake }\end{array}$ & $8.33^{a}$ & $8.67^{\mathrm{b}}$ & $8.68^{b}$ & $8.60^{b}$ & 0.10 \\
\hline $\operatorname{DCP}(g / d)$ & 592.8 & 623.4 & 628.6 & 619.3 & 7.79 \\
\hline $\operatorname{DCP}\left(\mathrm{g} / \mathrm{kg} \mathrm{w}^{0.75}\right)$ & 10.36 & 10.93 & 10.97 & 10.63 & 0.33 \\
\hline $\operatorname{TDN}(\mathrm{kg} / \mathrm{d})$ & 4.07 & 4.19 & 4.27 & 4.16 & 0.06 \\
\hline $\operatorname{TDN}\left(\mathrm{g} / \mathrm{kgw}^{0.75}\right)$ & 70.95 & 73.35 & 74.53 & 71.43 & 1.78 \\
\hline $\mathrm{ME}(\mathrm{MJ} / \mathrm{d})$ & 61.56 & 63.35 & 64.57 & 62.92 & 0.86 \\
\hline $\mathrm{ME}\left(\mathrm{MJ} / \mathrm{kg} \mathrm{w}^{0.75}\right)$ & 1.07 & 1.11 & 1.13 & 1.08 & 0.03 \\
\hline Nintake $(g / d)$ & 141.1 & 139.6 & 142.1 & 139.6 & 0.75 \\
\hline \multicolumn{6}{|l|}{ N loss } \\
\hline Faeces (g/d) & 25.56 & 23.44 & 24.31 & 23.52 & 1.43 \\
\hline Urine $(g / d)$ & 77.95 & 78.03 & 75.63 & 72.59 & 8.11 \\
\hline Total (g/d) & 105.89 & 99.85 & 97.81 & 97.47 & 8.42 \\
\hline $\mathrm{N}$ balance $(\mathrm{g} / \mathrm{d})$ & 37.64 & 38.12 & 42.17 & 43.53 & 8.62 \\
\hline $\mathrm{N}$ balance (\% intake) & 26.54 & 27.32 & 29.67 & 31.19 & 6.17 \\
\hline $\mathrm{N}$ balance $(\%$ absorbed $)$ & 32.22 & 32.88 & 35.83 & 37.61 & 7.35 \\
\hline
\end{tabular}

† Each value is an average of four observations; ab - values bearing different superscripts in a row differ significantly $(\mathrm{P}<0.05)$

complete diets compared to control (Table-3). However, no statistical differences were observed among the yeast-supplemented diets. Further, the DCP (\%) of the ration was not significantly $(\mathrm{P}>0.05)$ higher in yeastsupplemented diets in comparison to control. Intake of DCP $\left(\mathrm{g} / \mathrm{d}\right.$ or $\left.\mathrm{g} / \mathrm{kg} \mathrm{w}^{0.75}\right)$, TDN $\left(\mathrm{kg} / \mathrm{d}\right.$ or $\left.\mathrm{g} / \mathrm{kg} \mathrm{w}^{0.75}\right)$ and $\mathrm{ME}\left(\mathrm{MJ} / \mathrm{d}\right.$ or $\left.\mathrm{MJ} / \mathrm{kg} \mathrm{w}^{0.75}\right)$ in Murrah buffalo steers were not $(\mathrm{P}>0.05)$ affected by the levels of yeast in the diet but the values were numerically higher compared to control (Table-3).

Effect on nitrogen balance: Neither nitrogen $(\mathrm{N})$ intake $(\mathrm{g} / \mathrm{d})$ nor $\mathrm{N}$ loss through faeces, urine $(\mathrm{g} / \mathrm{d})$ and total $\mathrm{N}$ $(\mathrm{g} / \mathrm{d})$ were $(\mathrm{P}>0.05)$ influenced by the level of yeast supplementation in the complete diet, which was reflected on $\mathrm{N}$ balance in Murrah buffalo steers (Table$3)$. Though $\mathrm{N}$ balance (g/d or per cent absorbed) values were higher in yeast-supplemented buffaloes, these values were not significantly $(\mathrm{P}>0.05)$ different from control.

\section{Discussion}

In the current study, we observed that the DMI was not affected ( $P>0.05)$ by any level $(\%)$ of the yeast supplemented in the diets. The results obtained are in congruent with Polsit et al. [17], who reported that the DMI would either be decreased or not affected by the inclusion of live yeast in cattle diet. Dry matter and fibre digestibility's were substantially influenced by the supplementation of yeast, while increased levels of yeast had no added advantage. Similar to present findings, increase in DM and crude fibre digestibility's was reported in calves [18] and non-significant improvements were reported in cows [19]. These differences in digestibility's might be attributed to different ration composition, types and amounts of yeast used.

The OM, CP, EE and NFE digestibility's were not affected by any inclusion level of thermo-tolerant yeast.
These results are congruent with Tripathi and Karim [20] who reported no influence of yeast culture supplementation on OM and CP digestibility's. Further, our results for EE and NFE are similar to that of Srinivas Kumar et al. [5] in Murrah buffaloes.

In the present study, NDF, ADF, cellulose and hemicellulose digestibility's were influenced $(\mathrm{P}<0.05)$ by thermo-tolerant yeast. However, no significant effect was observed with increasing percentage of yeast in diet. Similar results for NDF and ADF were observed by Fadel Elseed and Rania [21] in lactating buffaloes and Harikrishna et al. [22] in Nellore lambs. Likewise, Harikrishna et al. [23] also reported significant $(\mathrm{P}<0.05)$ increase in the digestibility of hemicellulose and cellulose in Nellore lambs fed yeast supplemented diet. Improved crude fibre, cellulose and hemicellulose digestibility's by yeast supplementation might be due to increased bacterial growth, as yeast provides necessary growth promoters and vitamins which support bacterial growth [24].

The results for ME in yeast-supplemented and non-supplemented diets are in accordance with Paryad and Rashidi [25], where the values are significantly $(\mathrm{P}<0.05)$ different. However, no influence on ME was recorded with increasing the percentage of yeast supplementation in diet. The values of TDN, ME and DCP intakes of diet supplemented with increasing level of yeast are at par with the recommended levels of ICAR [26]. TDN and DCP intakes are in agreement with Mahender et al. [11] where the Murrah buffaloes were fed with yeast supplemented complete ration. As in the present study, Rameshwar Singh et al. [27] observed non-significant effect on nitrogen balance with yeast based diet in crossbred cows.

\section{Conclusion}

From the present study it can be concluded that the supplementation of yeast at $0.1 \%$ level in straw based 
complete diet improves the digestibility's of DM, fibre, ADF, NDF, cellulose, hemicellulose and ME of the diet without affecting the DMI and $\mathrm{N}$ balance in Murrah buffalo steers. However, beyond $0.1 \%$ of yeast supplementation no significant effect on nutrient digestibility and intake were observed. Further studies are warranted in assessing the effect of yeast culture on rumen microbes, enzyme activities and fermentation parameters.

\section{Authors' contributions}

BB: Co-Investigator of the project and conceived the idea of conducting animal experiments, RR: Principal Investigator of the project, MSR and MP: Helped in sampling and data analysis, LVR: Coordinator of the project. All authors have contributed in drafting and revision of the manuscript. All authors read and approved the final manuscript.

\section{Acknowledgements}

The authors acknowledge the financial assistance received from the Department of Biotechnology (DBT), Ministry of Science and Technology, New Delhi, India to carry out this research work.

\section{Competing interests}

The authors declare that they have no competing interests.

\section{References}

1. Moallem, U., Lehrer, H., Livshitz, M., Zachut, M. and Yakoby, S. (2009) The effects of live yeast supplementation to dairy cows during the hot season on production, feed efficiency and digestibility. J. Dairy Sci., 92:343-351.

2. Reddy, G.V.N. and Bhima, B. (2003) Effect of yeast culture based diet on growth and nutrient utilization in deoni bull calves. Indian J. Anim. Nutr., 20: 101-104.

3. Malik, R. and Singh, R. (2009) Effect of yeast and fungi culture on in vitro ruminal fermentation. Indian J. Anim. Nutr., 26(1): 40-45.

4. Kung, L. and Muck, R.E. (1997) Animal response to silage additives. Proceedings of the conference on Silage: Field to feed bunk. North American Conference Hershey, PA, NRAES

5. Srinivas Kumar, D., Ramaprasad, J. and Raghavarao, E. (2011) Influence of diet supplementation with Saccharomyces cerevisiae on intake and nutrient utilization in Graded Murrah buffaloes. Vet. World, 4:22-24.

6. Kamra, D.N. (2005) Rumen microbial ecosystem. Curr. Sci. India, 89: 124-135.

7. Jin, L.Z., Ho, Y.W., Abdullah, N. and Jalaludin, S. 1998. Acid and bile tolerance of Lactobacillus isolated from chicken intestine. Lett. Appl. Microbiol., 27: 183-185.

8. Lopez, J. (2000) Probiotics in animal nutrition. Asian Australas. J. Anim. Sci., 13: 12-26.

9. Bhima, B., Sudhakara Reddy, M., Anjana Devi, T., Ramana Reddy, Y. and Venkateshwar Rao, L. (2010) Screening and characterization of stress tolerant Saccharomyces cerevisiae isolated from brewery effulents for animal probiotic application. The IIOABJ., 1:32-39.

10. Bhima, B., Ramana Reddy, Y., Pawani, M., Sudhakara Reddy, M. and Venkateshwar Rao, L. (2009) Rumen Fermentation Pattern in Murrah Buffalo Steers Fed on Straw Based Complete Diet Supplemented with Thermotolerant
Probiotic Yeast (Saccharomyces Cerevisiae) at graded levels. Indian J. Anim. Nutr., 26:239-242.

11. Mahender, M., Prasad, V.L.K. and Reddy, G.V.N. (2005) Effect of yeast culture based complete diets on the performance of lactating murrah buffaloes. Indian J. Anim. Nutr., 22: 173-176.

12. AOAC. (1997) Official Methods of Analysis of AOAC International. $16^{\text {th }}$ Edition. Gaithersburg, Maryland, USA.

13. Van Soest, P.I., Robertson, J.D. and Levis, B.A. (1991) Methods of dietary fibre, neutral detergent fibre, non starch polysaccharides in relation to animal nutrition. J. Dairy Sci., 74:3583-3597.

14. NRC. (1978) Nutrient Requirements of Dairy Cattle, 5th rev. edition. National Academy of Science, National Research Council, Washington, DC.

15. Snedecor, G.W. and Cochran, W.G. (1980) Stastical methods, $7^{\text {th }}$ edition. Iowa State University Press, Ames, Iowa, USA.

16. Duncan, D.B. (1955) Multiple range and multiple 'F' test. Biometrics, 11: 1-42.

17. Polsit, K., Chuelong, S., Siriuthane, T., Ittarat, S., Koatedoke, U., Cherdthong, A. and Khampa, S. (2011) Supplementation of Cassava and Durian Hull Fermented Yeast (Saccharomyces cerevisiae) on Rumen Fermentation and Average Daily Gain in Crossbred Native Cattle. Pakistan J. Nutr., 10: 1121-1125.

18. Hossain, S.A., Parnerkar, S., Haque, N., Gupta, R.S., Kumar, D. and Tyagi, A.K. (2012) Influence of dietary supplementation of live yeast (Saccharomyces cerevisiae) on nutrient utilization, ruminal and biochemical profiles of Kankrej calves. Int. J. Appl. Anim. Sci., 1:30-38.

19. Phondba, B.T., Kank, V.D., Patil, M.B., Gadegaonkar, G.M., Jagadale, S.D. and Bade, R.N. (2009) Effect of feeding probiotic feed supplement on yield and composition of milk in crossbred cows. Anim. Nutr. Feed Techn., 9(2):245-252.

20. Tripathi, M.K. and Karim, S.A. (2010) Effect of individual and mixed live yeast culture feeding on growth performance, nutrient utilization and microbial crude protein synthesis in lambs. Anim. Feed. Sci. Tech., 155: 163-171.

21. Fadel Elseed, A.M.A. and Rania, M.A.A. (2007) Effects of supplemental yeast (Saccharomyces cerevisiae) culture on NDF digestibility and rumen fermentation of forage sorghum hay in Nubian goat's kids. Res. J. Agric. Biol. Sci., 3: 133-137.

22. Harikrishna, Ch., Mahender, M., Ramana Reddy, Y., Gnana Prakash, M., Sudhakar, K., Pavani, M. (2012) Evaluation of in vitro gas production and nutrient digestibility of complete diets supplemented with different levels of thermotolerant yeast in Nellore rams. Vet. World, 5(8): 477-485.

23. Harikrishna, Ch., Mahender, M., Ramana Reddy, Y., Gnana Prakash, M., Sudhakar, K. and Pavani, M. (2012) Supplementation effect of thermotolerant yeast on nutrient utilization and rumen fermentation in Nellore lambs. Livest. Res. RuralDev., 25(5): 90.

24. Chaucheyras-Durand, F., Walkera, N.D. and Bach, A. (2008) Effects of active dry yeasts on the rumen microbial ecosystem: Past, present and future. Anim. Feed. Sci. Tech., 145:5-26.

25. Paryad, A. and Rashidi, M. (2009) Effect of Yeast (Saccharomyces cerevisiae) on Apparent Digestibility and Nitrogen Retention of Tomato Pomace in Sheep. Pakistan J. Nutr., 8: 273-278.

26. ICAR. (1998) Nutrient requirements of livestock and Poultry, ICAR, New Delhi.

27. Rameshwar Singh, Chaudhary, L.C., Kamra, D.N. and Pathak, N.N. (1998) Effect of dietary supplementation with yeast cell suspension (S. cerevisiae) on nutrient utilization and growth response in cross bred calves. Asian Australas. $J$. Anim. Sci., 112: 268-271. 